April - 2009

Regional Focus Issue: Bridge over Troubled Waters Cengiz Hakan Aydin and Yoram EshetAlkalai, IRRODL Regional Editors for the Middle East

\title{
Turkish University Students' Perceptions of the World Wide Web as a Learning Tool: An Investigation Based on Gender, Socio-Economic Background, and Web Experience
}

\author{
Erkan Tekinarslan \\ Abant Izzet Baysal University, Turkey
}

\begin{abstract}
The main purpose of the study is to investigate Turkish undergraduate students' perceptions of the Web as a learning tool and to analyze whether their perceptions differ significantly based on gender, socio-economic background, and Web experience. Data obtained from 722 undergraduate students (331 males and 391 females) were used in the analyses. The findings indicated significant differences based on gender, socio-economic background, and Web experience. The students from higher socio-economic backgrounds indicated significantly higher attitude scores on the self-efficacy subscale of the Web attitude scale. Similarly, the male students indicated significantly higher scores on the self-efficacy subscale than the females. Also, the students with higher Web experience in terms of usage frequency indicated higher scores on all subscales (i.e., self-efficacy, affective, usefulness, Web-based learning). Moreover, the two-way ANOVA results indicated that the student's PC ownership has significant main effects on their Web attitudes and on the usefulness, self-efficacy, and affective subscales.
\end{abstract}

Keywords: Web usage pattern; Web attitudes; gender; socio-economic background; Web experience

\section{Introduction}

In many societies, information and communication technologies have become progressively more widespread in education (Keller \& Cernerud, 2002). In particular, the role of the Internet continues to expand for both the delivery and support of courses in higher education. For instance, Internet usage in higher education spans a wide range from providing online support for traditional classroom-based courses through the placing of syllabi or readings on the Web to Internet-based delivery of entire courses (Brinkerhoff, Koroghlanian, 2005). 
The first Internet connection in Turkey, which has the demographics of a developing country with a GDP per capita of around US\$5,000 (Business Monitor International, 2008), was established in 1990 (Usun, 2003). Presently, the Internet penetration in Turkey is about 23\%, which is notably lower than the penetration rate $(50 \%)$ in developed European Union countries. However, the Internet penetration in Turkey is increasing rapidly with the introduction of a number of campaigns to boost Internet penetration in education and other sectors (Business Monitor International, 2008). Although several universities (i.e., Middle East Technical University, Ege University) were the dominant users of the Internet in the first six years, since 1996 the Internet in Turkey has entered many sectors, including banking, health, and all levels of education (Usun, 2003). Nevertheless, there have been more attempts to integrate the Internet into Turkish higher education than primary and secondary education. For instance, some Turkish universities, such as Anadolu University and Sakarya University, have begun to offer Web-based online degrees (Usun, 2003).

The World Wide Web, which is an Internet-based network of information resources, combines text and multimedia. The Web started to become a popular resource after 1993 when the first widely distributed browser provided a convenient way to access a variety of information on the Internet (Microsoft Encarta Online Encyclopedia, 2007). Today, most Turkish universities have proper Internet connections, and a variety of educational information is provided to students on their Web sites. According to Liaw (2002b), understanding learners' perceptions of information technology is useful and necessary before or during their use of it as an assisted learning tool. The term perception in this study is considered to be the attitudes and feelings the students have toward the Web as a learning tool. However, Turkish university students' perceptions of the Web as a learning tool have not been sufficiently investigated, although some studies are emerging. Therefore, this study focuses on Turkish undergraduate students' perceptions of the Web as a learning tool.

\section{Purpose of the Study}

The main purpose of the study is to investigate Turkish undergraduate students' perceptions of the Web as a learning tool and to analyze whether their perceptions differ based on gender, socioeconomic background, and Web experience. Moreover, this study also investigates whether there are any differences in the Web usage pattern of Turkish students based on gender, socioeconomic background, and perceptions of the Web as a learning tool. Specifically, this study investigates the following research questions:

1. What is the Internet or Web usage pattern of Turkish undergraduate students?

2. Are there any differences in the Web usage pattern based on gender, socio-economic background, and perceptions or attitudes toward the Web as a learning tool?

3. Are there any differences in perceptions of the Web as a learning tool based on gender and socio-economic background?

4. Are there any differences in perceptions of the Web as a learning tool based on personal computer (PC) ownership? 
5. Are there any differences in perceptions of the Web as a learning tool based on Webusage frequency?

6. Are there any main or interaction effects of socio-economic background, PC ownership, and gender on the students' perceptions of the Web as a learning tool?

\section{Literature Review}

In regard to gender issues, some prior studies (e.g., Sam, et al., 2005; Carswell et al., 2000) revealed that the attitudes of male and female students toward Internet use in educational environments do not differ significantly. However, some other studies (i.e., Durndell \& Haag, 2002; Schumacher \& Morahan-Martin, 2001) indicated that male students tend to reflect more positive attitudes toward Internet use. Thus, there is no consistency among the findings of prior studies about the relationship between gender and Internet attitudes.

Moreover, most prior studies (e.g., Liaw, 2002b; Durndell \& Haag, 2002; Luan, et al., 2005; Anderson \& Reed, 1998) that investigated the relationship between Web experience and Web attitude found that students with higher Web experience indicate more positive attitudes toward the Web as a learning tool.

Furthermore, prior literature (e.g., Bozioneloss, 2004; Haseloff, 2005) suggests that socioeconomic background has a strong positive relationship with computer or Internet experience. For instance, Haseloff's (2005) study in India indicated that Internet usage drastically decreases in the lower socio-economic and income classes.

\section{Methodology}

\section{Participants}

The questionnaire was distributed to 741 Turkish undergraduate university students at Abant Izzet Baysal University in the 2008 spring semester, but the data obtained from 19 students were excluded from the analyses since the students' responses on the questionnaire were incomplete. The data obtained from 722 students (331 males and 391 females) in different faculties or schools, such as the Faculty of Literature and Science $(n=145)$, the Faculty of Education $(n=$ $260)$, the Faculty of Management and Business Administration $(n=224)$ and the School of Physical Education and Sport $(n=93)$, were used in the analyses.

\section{Research Instrument}

A questionnaire consisting of two sections was used to collect data. The first section was used to collect data for demographical characteristics (e.g., gender, socio-economic background) and computer and Web experience (e.g., PC ownership, Web-usage frequency, Web-usage activities). The second section of the questionnaire contains a Likert-type Web attitude scale with 21 items. The first 16 items of the scale were adapted from a Web attitude scale (WAS) developed by Liaw 
(2002a). The rationale for the use of WAS in this study is that it has high internal consistency, stability, and validity (Liaw, 2002a), and it has been used in other studies (e.g., Akpinar \& Bayramoğlu, 2008; Yang \& Lester, 2003). Moreover, before obtaining the data from the Turkish students, the original WAS with 16 items in English was translated to Turkish by the researcher, and the translation was validated by a linguist who is proficient in English and Turkish. The last five items of the scale were adapted from an attitude scale toward Internet-based learning developed by Tekinarslan (2008) in Turkish to measure more specifically the students' attitudes toward Web-based learning.

\section{Validity and Reliability of the Attitude Scale}

After collecting the data from the 722 students through the 21-item Web attitude scale, both the Barlett's Test of Sphericity and the Kaiser-Meyer-Olkin (KMO) measure of sampling adequacy were performed to examine whether the data set was appropriate for a factor analysis. The KMO measure of sampling adequacy was high $(0.933)$ and significant $(\mathrm{P}=0.000)$. Barlett's Test of Sphericity was also notably high and significant (chi-square $=9155.720$ with 210 degree of freedom at $\mathrm{P}=0.000$ ). Then an explanatory factor analysis (principle components, varimax rotation with Kaiser Normalization) was applied to analyze the items and to clarify the structure of the Web attitude scale. The analysis identified four factors with eigenvalues $>1$. The items and responding factors (subscales) in the scale are represented in Table 1.

Table 1

Rotated Factor Loadings and Cronbach's $\alpha$ Coefficients for the Four Factors (Subscales) of the Web Attitude Scale

\begin{tabular}{|c|c|c|c|c|}
\hline Items & $\begin{array}{l}\text { Factor 1: } \\
\text { Usability } \\
\alpha=0.90\end{array}$ & $\begin{array}{l}\text { Factor 2: } \\
\text { Web-based } \\
\text { Learning } \\
\alpha=0.89\end{array}$ & $\begin{array}{l}\text { Factor 3: } \\
\text { Self-efficacy } \\
\alpha=0.85\end{array}$ & $\begin{array}{l}\text { Factor } \\
\text { Affective } \\
\alpha=0.72\end{array}$ \\
\hline 10 & .778 & & & \\
\hline 15 & .763 & & & \\
\hline 12 & .741 & & & \\
\hline 13 & .720 & & & \\
\hline 9 & .643 & & & .431 \\
\hline 16 & .633 & .373 & & \\
\hline 11 & .630 & & & \\
\hline 21 & .619 & .470 & & \\
\hline 14 & .554 & .452 & & \\
\hline 19 & & .843 & & \\
\hline 20 & & .826 & & \\
\hline 18 & & .745 & & \\
\hline
\end{tabular}




$\begin{array}{lllll}17 & .475 & .637 & .850 & \\ 3 & & .833 & \\ 1 & & .746 & \\ 2 & & .736 & .716 \\ 4 & & & .613 \\ 6 & .332 & & .608 \\ 5 & & & .553 \\ 7 & & .363 & 1.417 \\ 8 & & 14.098 & 1.190\end{array}$

As expected, the items adapted from the WAS (Liaw, 2002a) and the Internet-based learning attitude scale (IBLAS) (Tekinarslan, 2008) generally loaded under different factors, although an item (item 21) adapted from the IBLAS loaded higher under one of the factors structured with the items of WAS. However, in the following analyses, item 21 was used under a factor that covers the items from the IBLAS since it was more related to contents of other relevant items under the factor. Moreover, the items adapted from the WAS loaded under three different factors and they were named as self-efficacy, affective, and usefulness by considering the characteristics of the WAS described by Liaw (2002a) and the contents of the relevant items. Additionally, the factor which covers the items from the IBLAS was named as Web-based learning based on the contents of the relevant items.

As indicated in Table 1, the factor loadings of the relevant items differ between $0.778-0.554$, $0.637-0.470,0.850-0.736$ and $0.716-0.553$ respectively for usability, learning, self-efficacy, and affective factors or subscales. The factor loadings of the items can be considered as sufficient and they reflect evidence for the factorial validity and construct validity of the scale (Thompson \& Daniel, 1996).

Table 2

The Items and the Factors (Subscales) on the Attitude Scale toward the Web

\begin{tabular}{|c|c|c|}
\hline Item $\mathrm{No}^{*}$ & Subscale & Question \\
\hline 10 & Usability & The Internet/Web helps me to find information. ${ }^{a}$ \\
\hline 15 & Usability & $\begin{array}{l}\text { I believe that learning how to use the Internet/Web is } \\
\text { worthwhile. }\end{array}$ \\
\hline 12 & Usability & $\begin{array}{l}\text { The multimedia environment of Web (e.g. text, image) is } \\
\text { helpful to understand online information. }{ }^{\text {a }}\end{array}$ \\
\hline 13 & Usability & I believe the Internet/Web has potential as a learning tool. ${ }^{a}$ \\
\hline 9 & Usability & I believe using the Internet/Web is worthwhile. ${ }^{a}$ \\
\hline 16 & Usability & Learning the Internet/Web skills can enhance my academic \\
\hline
\end{tabular}




\begin{tabular}{|c|c|c|}
\hline & & performance. $^{\mathrm{a}}$ \\
\hline 11 & Usability & I believe the Internet/Web makes communication easier. ${ }^{a}$ \\
\hline 14 & Usability & $\begin{array}{l}\text { I believe that the Internet/Web is able to offer online learning } \\
\text { activities. }{ }^{\text {a }}\end{array}$ \\
\hline 21 & $\begin{array}{l}\text { Web-based } \\
\text { learning }\end{array}$ & I believe the Web contributes greatly to life-long learning. \\
\hline 19 & $\begin{array}{l}\text { Web-based } \\
\text { learning }\end{array}$ & $\begin{array}{l}\text { I suppose that taking a course in the Web environment must } \\
\text { be enjoyable. }{ }^{\text {b }}\end{array}$ \\
\hline 20 & $\begin{array}{l}\text { Web-based } \\
\text { learning }\end{array}$ & $\begin{array}{l}\text { I would like to take a course in the Web environment if I } \\
\text { have chance to. }\end{array}$ \\
\hline 18 & $\begin{array}{l}\text { Web-based } \\
\text { learning }\end{array}$ & The idea of Web-based learning is exciting. ${ }^{b}$ \\
\hline 17 & $\begin{array}{l}\text { Web-based } \\
\text { learning }\end{array}$ & I like to learn in the Web environment. ${ }^{\mathrm{b}}$ \\
\hline 3 & Self-efficacy & $\begin{array}{l}\text { I feel confident using Web browsers (e.g. Internet Explorer, } \\
\text { Netscape Communicator). }{ }^{\text {a }}\end{array}$ \\
\hline 1 & Self-efficacy & I feel confident using the Internet/Web. ${ }^{a}$ \\
\hline 2 & Self-efficacy & I feel confident using e-mail. ${ }^{\text {a }}$ \\
\hline 4 & Self-efficacy & $\begin{array}{l}\text { I feel confident using search engines (e.g. Yahoo, Excite, and } \\
\text { Lycos). }{ }^{a}\end{array}$ \\
\hline 6 & Affective & I enjoy talking with others about the Internet. ${ }^{a}$ \\
\hline 5 & Affective & I like to use e-mail to communicate with others. ${ }^{a}$ \\
\hline 7 & Affective & I like to work with the Internet/Web. ${ }^{a}$ \\
\hline 8 & Affective & I like to use the Internet from home. ${ }^{\text {a }}$ \\
\hline
\end{tabular}

Furthermore, as indicated in Table 1 , the internal reliability coefficients are high $(\alpha=0.90, \alpha=$ $0.89, \alpha=0.85)$ and sufficient $(\alpha=0.72)$ respectively for usability, learning, self-efficacy, and affective subscales and for the entire scale $(\alpha=0.93)$. According to these findings, the scale has a high reliability in general.

Moreover, the items and responding factors (subscales) in the Web attitude scale are represented in Table 2. The descriptive results for the students' scores on the subscales are indicated in Table 3. The higher mean scores of the participants on the subscales indicate better attitudes toward the Web as a learning tool.

Table 3

The Students' Scores on the Subscales of the Web Attitude Scale

\begin{tabular}{|c|c|c|c|c|c|c|}
\hline Factors & $\mathrm{N}$ & Items & Possible & Range & Mean & Dev. \\
\hline
\end{tabular}




\begin{tabular}{|c|c|c|c|c|c|c|}
\hline & & & range & & $(\bar{X})$ & (sd) \\
\hline Usability & 722 & 8 & $8-40$ & 32 & 33.73 & 5.52 \\
\hline Web-based learning & 722 & 5 & $5-25$ & 20 & 19.44 & 4.37 \\
\hline Self-efficacy & 722 & 4 & $4-20$ & 16 & 14.72 & 3.57 \\
\hline Affective & 722 & 4 & $4-20$ & 16 & 15.17 & 3.17 \\
\hline
\end{tabular}

\section{Data Collection and Data Analysis Procedures}

The data analyses were carried out with the Statistical Packages for Social Sciences (SPPS). After the explanatory factor analysis, descriptive statistics, chi-square tests, t-tests, and one-way and two-way ANOVAs were used to analyze the data.

\section{Results}

\section{Web Use Pattern}

The Turkish undergraduate students $(N=722)$ responded that they mostly use the Internet or Web for the following activities: research through search engines $(86.3 \%, n=623)$; e-mail services (76.3\%, $n=551)$; news reading $(69.5 \%, n=502)$; entertainment (e.g., games, music, etc.) $(69.1 \%, n=499)$; education (e.g., reading electronic papers, etc.) $(64 \%, n=462)$; software downloading $(62.2 \%, n=449)$; and chat $(60.1 \%, n=434)$. On the other hand, a notably lower number of students responded that they use the Internet for participation in discussion groups and forums $(23.8 \%, n=172)$ and for shopping $(18.3 \%, n=132)$.

\section{Differences in the Web Use Pattern Based on Gender}

The gender differences in the Web use pattern for the common Web activities are shown in Table 4. Significantly, more Turkish male students in comparison to female students have used the Web for shopping $\left(\chi^{2}=18.87, \mathrm{df}=1, \mathrm{p}=.000\right)$, software downloading $\left(\chi^{2}=36.37, \mathrm{df}=1, \mathrm{p}=.000\right)$, news reading $\left(\chi^{2}=26.72, \mathrm{df}=1, \mathrm{p}=.000\right)$, participation in discussion groups and forums $\left(\chi^{2}=\right.$ 21.01, $\mathrm{df}=1, \mathrm{p}=.000)$, and entertainment activities $\left(\chi^{2}=14.10, \mathrm{df}=1, \mathrm{p}=.000\right)$.

Table 4

Differences in Using the Web for Common Web Activities Based on Gender

\begin{tabular}{lllllll}
\hline & Male & \multicolumn{5}{c}{ Female } \\
& $(\mathrm{N}=331)$ & & & & \\
& Yes & No & Yes & No & & \\
Web activities & $\mathrm{N}$ & $\mathrm{N}$ & $\mathrm{N}$ & $\mathrm{N}$ & $\chi^{2}$ & $\mathrm{P}$ \\
\hline
\end{tabular}




\begin{tabular}{lllllll}
\hline Shopping & 83 & 248 & 49 & 342 & 18.87 & $.000^{*}$ \\
Software downloading & 245 & 86 & 204 & 187 & 36.37 & $.000^{*}$ \\
E-mail & 261 & 70 & 290 & 101 & 2.17 & .140 \\
Chat & 205 & 126 & 229 & 162 & .847 & .357 \\
Entertainment & 252 & 79 & 247 & 144 & 14.10 & $.000^{*}$ \\
Research & 270 & 61 & 353 & 38 & 11.49 & $.001^{*}$ \\
Education (e.g., reading & 200 & 131 & 262 & 129 & 3.37 & .066 \\
electronic papers) & 262 & 69 & 240 & 151 & 26.72 & $.000^{*}$ \\
News reading & 105 & 226 & 67 & 324 & 21.01 & $.000^{*}$ \\
Discussion groups and forums & 105 & & & & &
\end{tabular}

However, significantly more Turkish female students have used the Web for research purposes as compared to male students $\left(\chi^{2}=11.49, \mathrm{df}=1, \mathrm{p}=.001\right)$. Furthermore, the gender difference in the use of the Web for educational purposes was close to significance level $(\chi 2=3.37$, $\mathrm{df}=1, \mathrm{p}=$ .066) in favor of the females. However, there were no gender differences in the Web usage for email and chat purposes.

Table 5

Differences in Using the Web for the Common Web Activities Based on Monthly Family Incomes in New Turkish Lira (NTL)

\begin{tabular}{|c|c|c|c|c|c|c|c|c|c|c|c|c|}
\hline \multirow[b]{2}{*}{$\begin{array}{l}\text { Web } \\
\text { activities }\end{array}$} & \multicolumn{2}{|c|}{$\begin{array}{l}<750 \mathrm{NTL} \\
(\mathrm{N}=116)\end{array}$} & \multicolumn{2}{|c|}{$\begin{array}{l}750-1500 \\
\text { NTL } \\
(\mathrm{N}=353)\end{array}$} & \multicolumn{2}{|c|}{$\begin{array}{l}1501-2250 \\
\text { NTL } \\
(\mathrm{N}=353)\end{array}$} & \multicolumn{2}{|c|}{$\begin{array}{l}2251-3000 \\
\text { NTL } \\
(\mathrm{N}=59)\end{array}$} & \multicolumn{4}{|c|}{$\begin{array}{l}>3000 \\
\text { NTL } \\
(\mathrm{N}=28)\end{array}$} \\
\hline & $\begin{array}{l}\text { Yes } \\
\mathrm{N}\end{array}$ & $\begin{array}{l}\text { No } \\
\mathrm{N}\end{array}$ & $\begin{array}{l}\text { Yes } \\
\mathrm{N}\end{array}$ & $\begin{array}{l}\text { No } \\
\mathrm{N}\end{array}$ & $\begin{array}{l}\text { Yes } \\
\mathrm{N}\end{array}$ & $\begin{array}{l}\text { No } \\
\mathrm{N}\end{array}$ & $\begin{array}{l}\text { Yes } \\
\mathrm{N}\end{array}$ & $\begin{array}{l}\text { No } \\
\mathrm{N}\end{array}$ & $\begin{array}{l}\text { Yes } \\
\mathrm{N}\end{array}$ & $\begin{array}{l}\mathrm{No} \\
\mathrm{N}\end{array}$ & $\chi^{2}$ & $\mathrm{P}$ \\
\hline Shopping & 15 & 101 & 51 & 302 & 32 & 134 & 22 & 37 & 12 & 16 & 31.391 & $.000 *$ \\
\hline $\begin{array}{l}\text { Software } \\
\text { downloading }\end{array}$ & 59 & 57 & 208 & 145 & 120 & 46 & 42 & 17 & 20 & 8 & 18.179 & $.001 *$ \\
\hline E-mail & 75 & 41 & 270 & 83 & 134 & 32 & 51 & 8 & 21 & 7 & 13.889 & $.008 *$ \\
\hline Chat & 63 & 53 & 201 & 152 & 111 & 55 & 40 & 19 & 19 & 9 & 8.422 & .077 \\
\hline Entertainment & 76 & 40 & 234 & 119 & 117 & 49 & 52 & 7 & 20 & 8 & 12.239 & $.016^{*}$ \\
\hline Research & 102 & 14 & 302 & 51 & 147 & 19 & 50 & 9 & 22 & 6 & 2.674 & .614 \\
\hline Education & 73 & 43 & 217 & 136 & 112 & 54 & 42 & 17 & 18 & 10 & 3.226 & .521 \\
\hline
\end{tabular}




\begin{tabular}{lcccccccccccc}
$\begin{array}{l}\text { News reading } \\
\begin{array}{l}\text { Discussion } \\
\text { groups and } \\
\text { forums }\end{array}\end{array}$ & 74 & 42 & 237 & 116 & 124 & 42 & 47 & 12 & 20 & 8 & 7.754 & .101 \\
\hline$* \mathrm{P}<.05$ & 94 & 88 & 265 & 38 & 128 & 16 & 43 & 8 & 20 & 2.527 & .640 \\
\end{tabular}

\section{Differences in the Web Use Pattern Based on Socio-economic Background}

The socio-economic backgrounds of the students were categorized depending on their families' monthly incomes in New Turkish Liras (NTL) (1 US\$ $\cong 1.6$ NTL): less than 750 NTL, between 750 and 1500 NTL, between 1501 and 2250 NTL, between 2251 and 3000 NTL, and over 3000 NTL.

As displayed in Table 5, there were significant differences in the Web use pattern for four Web activities, namely shopping $\left(\chi^{2}=31.39, \mathrm{df}=4, \mathrm{p}=.000\right)$, software downloading $\left(\chi^{2}=18.17, \mathrm{df}=\right.$ $4, \mathrm{p}=.001)$, e-mail $\left(\chi^{2}=13.88, \mathrm{df}=1, \mathrm{p}=.008\right)$, and entertainment $\left(\chi^{2}=12.23\right.$, df $\left.=4, \mathrm{p}=.016\right)$, in favor of the students from higher socio-economic backgrounds. In general, notably fewer students with a monthly family income of less than 750 NTL have used the Web for these activities (i.e., shopping, software downloading, e-mail, entertainment) as compared to the numbers of students with higher monthly family incomes (i.e., $1501-2250$ NTL, $2251-3000$ NTL, and over 3000 NTL). Moreover, the socio-economic background difference in the Web usage for chat activities was close to significance level $(\chi 2=8.42, \mathrm{df}=4, \mathrm{p}=.077)$ in favor of students from the higher socio-economic backgrounds. However, there were no socio-economic background differences in Web usage for activities such as research, education, news reading, and discussion groups and forums.

\section{Differences in the Web Use Pattern Based on Perceptions toward the Web}

As displayed in Table 6, the t-test results showed that students who have used the Web for the seven common activities (i.e., shopping, software downloading, news reading, e-mail, chat, entertainment, discussion groups and forums) indicated significantly more positive attitudes or perceptions toward the Web on all of the subscales (i.e., self-efficacy, affective, usefulness, Webbased learning) at .05 level. In addition, the students who have used the Web for educational activities (e.g., reading electronic papers) showed significantly higher attitudes toward the Web on self-efficacy and affective subscales than the students who have not. Furthermore, the students who have used the Web for research activities indicated significantly higher attitudes on the affective subscale than the students who have not.

On the other hand, the mean scores of the students who have and have not used the Web for educational activities did not differ significantly on the usefulness and Web-based learning subscales. Similarly, attitudes of the students who have and have not used the Web for research activities did not differ significantly on the usefulness, Web-based learning, and self-efficacy subscales. These findings revealed that the Turkish undergraduates $(n=462$ out of 722$)$ have 
used the Web for educational activities regardless of their attitudes on the usefulness and Webbased learning subscales. Similarly, regardless of their levels of Web attitude on the usefulness, Web-based learning, and self-efficacy subscales, most of them $(n=623$ out of 722$)$ have used the Web mainly for research activities.

Table 6

Differences in Using the Web for Common Web Activities Based on Attitudes toward the Web

\begin{tabular}{|c|c|c|c|c|c|c|c|c|c|c|c|c|c|c|c|c|c|c|}
\hline & \multirow[b]{3}{*}{ Yes } & \multirow[b]{3}{*}{ No } & \multicolumn{16}{|c|}{ Subscales } \\
\hline & & & \multicolumn{4}{|c|}{ Usefulness } & \multicolumn{4}{|c|}{ Web-based learning } & \multicolumn{4}{|c|}{ Self-efficacy } & \multicolumn{4}{|c|}{ Affective } \\
\hline & & & Yes & No & & & Yes & No & & & Yes & No & & & Yes & No & & \\
\hline $\begin{array}{l}\text { Common } \\
\text { Web } \\
\text { activities }\end{array}$ & $\mathrm{N}$ & $\mathrm{N}$ & $\bar{X}$ & $\bar{X}$ & $\mathrm{t}$ & $\mathrm{p}$ & $\bar{X}$ & $\bar{X}$ & $\mathrm{t}$ & $\mathrm{p}$ & $\bar{X}$ & $\bar{X}$ & $\mathrm{t}$ & $\mathrm{p}$ & $\bar{X}$ & $\bar{X}$ & $\mathrm{t}$ & $\mathrm{p}$ \\
\hline Shopping & 132 & 590 & 34.93 & 33.46 & 2.77 & $.006^{*}$ & 20.47 & 19.21 & 3.01 & $.003^{*}$ & 16.03 & 14.93 & 4.70 & $.000^{*}$ & 16.04 & 14.98 & 3.50 & $.000^{*}$ \\
\hline $\begin{array}{l}\text { Downloading } \\
\text { software }\end{array}$ & 449 & 273 & 34.22 & 32.92 & 3.08 & $.002^{*}$ & 19.83 & 18.80 & 3.11 & $.002^{*}$ & 15.66 & 13.18 & 9.58 & $.000 *$ & 15.62 & 14.43 & 4.97 & $.000 *$ \\
\hline E-mail & 551 & 171 & 34.12 & 32.45 & 3.48 & $.001^{*}$ & 19.80 & 18.29 & 3.97 & $.000^{*}$ & 15.31 & 12.81 & 8.37 & $.000^{*}$ & 15.58 & 13.85 & 6.40 & $.000 *$ \\
\hline Chat & 434 & 288 & 34.26 & 32.92 & 3.21 & $.001^{*}$ & 19.73 & 19.01 & 2.15 & $.031^{*}$ & 15.03 & 14.25 & 2.90 & $.004^{*}$ & 15.65 & 14.45 & 5.06 & $.000^{*}$ \\
\hline $\begin{array}{l}\text { Entertain- } \\
\text { ment }\end{array}$ & 499 & 2.23 & $34 . .35$ & 32.34 & 4.55 & $.000 *$ & 19.85 & 18.54 & 3.75 & $.000 *$ & 15.31 & 13.41 & 6.79 & $.000^{*}$ & 15.68 & 14.04 & 6.61 & $.000 *$ \\
\hline Research & 623 & 99 & 33.88 & 32.78 & 1.83 & .067 & 19.56 & 18.69 & 1.84 & .066 & 14.77 & 14.39 & .993 & .321 & 15.27 & 14.54 & 2.13 & $.033^{*}$ \\
\hline Education & 462 & 260 & 33.89 & 33.43 & 1.07 & .283 & 19.50 & 19.35 & .449 & .654 & 15.01 & 14.21 & 2.86 & $.004^{*}$ & 15.51 & 14.58 & 3.79 & $.000^{*}$ \\
\hline $\begin{array}{l}\text { News } \\
\text { reading }\end{array}$ & 502 & 220 & 34.04 & 33.01 & 2.23 & $.020^{*}$ & 19.75 & 18.73 & 2.90 & $.004^{*}$ & 15.17 & 13.70 & 5.16 & $.000^{*}$ & 15.42 & 14.61 & 3.15 & $.002^{*}$ \\
\hline $\begin{array}{l}\text { Discussion } \\
\text { groups and } \\
\text { forum }\end{array}$ & 172 & 550 & 34.69 & 33.43 & 2.63 & $.009 *$ & 20.47 & 19.12 & 3.56 & $.000^{*}$ & 16.19 & 14.26 & 6.34 & $.000^{*}$ & 16.20 & 14.85 & 4.93 & $.000 *$ \\
\hline
\end{tabular}

\section{Differences in Perceptions toward the Web Based on Gender}

The t-test results indicated that mean attitude scores $(\bar{X})$ of the male $(N=331, \bar{X}=15.25)$ and female students $(N=391, \bar{X}=14.27)$ on self-efficacy subscale differ significantly in favor of the male students $(\mathrm{t}=-3.679, \mathrm{df}=720, \mathrm{p}=.000)$. However, there were no significant differences at 0.05 level in the mean attitude scores of the male and female students on the affective $(t=.392$, $\mathrm{df}=720, \mathrm{p}=.695)$, usefulness $(\mathrm{t}=1.021, \mathrm{df}=720, \mathrm{p}=.307)$, and Web-based learning $(\mathrm{t}=-.033$, $\mathrm{df}=720, \mathrm{p}=.974)$ subscales.

\section{Differences in Perceptions toward the Web Based on Socio-economic Background}

As displayed in Table 7, the one-way ANOVA results on differences based on the socioeconomic backgrounds in terms of monthly family incomes indicated that there were significant 
differences in the mean scores of the students on the self-efficacy subscale $(F=4.306, \mathrm{df}=4 / 717$, $\mathrm{p}=0.002$ ). Specifically, post-hoc analysis (Tukey HSD) revealed that the students whose families have less than 750 NTL monthly income had significantly lower attitude mean scores than the students whose families have higher monthly incomes (i.e., $1501-2250$ NTL, and 2251 -3000 NTL) on the self-efficacy subscale.

Table 7

Differences in Perceptions toward the Web Based on Socio-Economic Background

\begin{tabular}{|c|c|c|c|c|c|}
\hline & & Usefulness & $\begin{array}{l}\text { Web-based } \\
\text { learning }\end{array}$ & Self-efficacy & Affective \\
\hline Monthly family income & $\mathrm{N}$ & $\bar{X} \quad(\mathrm{sd})$ & $\bar{X} \quad(\mathrm{sd})$ & $\bar{X} \quad(\mathrm{sd})$ & $\bar{X} \quad(\mathrm{sd})$ \\
\hline (1) $<750 \mathrm{NTL}$ & 116 & $33.77(5.41)$ & $19.24(4.77)$ & $13.81(4.15)$ & $14.87(3.48)$ \\
\hline (2) $750-1500 \mathrm{NTL}$ & 353 & $33.44(5.45)$ & $19.36(4.30)$ & $14.60(3.49)$ & $15.15(2.96)$ \\
\hline (3) $1501-2250 \mathrm{NTL}$ & 166 & $33.63(6.14)$ & $19.67(4.27)$ & $15.10(3.34)$ & $15.32(3.41)$ \\
\hline (4) $2251-3000 \mathrm{NTL}$ & 59 & $35.23(3.07)$ & $19.52(4.23)$ & $15.83(2.90)$ & $15.35(2.91)$ \\
\hline (5) $>3000 \mathrm{NTL}$ & 28 & $34.60(6.59)$ & $19.78(4.52)$ & $15.53(3.85)$ & $15.46(3.61)$ \\
\hline F (ANOVA) & & $\begin{array}{l}1.533 \\
(\mathrm{P}=.191)\end{array}$ & $\begin{array}{l}.251 \\
(\mathrm{P}=.909)\end{array}$ & $\begin{array}{l}4.306 \\
(\mathrm{P}=.002)^{*}\end{array}$ & $\begin{array}{l}.467 \\
(\mathrm{P}=.760)\end{array}$ \\
\hline Tukey HSD & & & & $\begin{array}{l}(3)>(1)^{*} \\
(4)>(1)^{*}\end{array}$ & \\
\hline
\end{tabular}

$* \mathrm{P}<0.05$

However, the one-way ANOVA results on differences based on the socio-economic backgrounds also indicated that the differences in the mean scores of the students on the affective $(\mathrm{F}=.467$, $\mathrm{df}$ $=4 / 717, \mathrm{p}=0.760)$, usefulness $(\mathrm{F}=1.533, \mathrm{df}=4 / 717, \mathrm{p}=0.191)$, and Web-based learning $(\mathrm{F}=$ $.251, \mathrm{df}=4 / 717, \mathrm{p}=0.909)$ subscales were not significant at .05 level.

\section{Differences in Perceptions toward the Web Based on PC Ownership}

The t-test results in Table 8 indicated that mean attitude scores $(\bar{X})$ of the PC-owner students $(N$ $=445)$ and the non-PC-owners $(N=277)$ on three subscales (usefulness, self-efficacy, affective) differ significantly at .05 level in favor of the PC-owner students. However, there were no significant differences in the mean attitude scores of the PC-owner and non-PC-owner students on the Web-based learning subscale. 
Table 8

Differences in Perceptions toward the Web Based on PC Ownership

\begin{tabular}{|c|c|c|c|c|c|c|c|c|c|c|c|c|c|}
\hline \multirow{2}{*}{$\begin{array}{l}\text { PC } \\
\text { ownership }\end{array}$} & \multicolumn{3}{|c|}{ Usefulness } & \multicolumn{4}{|c|}{$\begin{array}{l}\text { Web-based } \\
\text { learning }\end{array}$} & \multicolumn{2}{|c|}{ Self-efficacy } & \multicolumn{4}{|c|}{ Affective } \\
\hline & $\mathrm{N}$ & $\bar{X}$ & $\mathrm{t}$ & $\mathrm{p}$ & $\bar{X}$ & $\mathrm{t}$ & $\mathrm{p}$ & $\bar{X}$ & $\mathrm{t}$ & $\mathrm{p}$ & $\bar{X}$ & $\mathrm{t}$ & $\mathrm{p}$ \\
\hline $\begin{array}{l}\text { PC } \\
\text { owners } \\
\text { Non-PC } \\
\text { owners }\end{array}$ & 445 & 34.36 & 3.960 & $.000^{*}$ & $\begin{array}{l}19.66 \\
19.10\end{array}$ & 1.682 & .093 & $\begin{array}{l}15.55 \\
13.38\end{array}$ & 8.275 & $.000 *$ & $\begin{array}{l}15.60 \\
14.49\end{array}$ & 4.595 & $.000 *$ \\
\hline
\end{tabular}

*Degree of freedom $(\mathrm{df})=720$ in all cases.

$* \mathrm{P}<.05$

\section{Differences in Perceptions toward the Web Based on Frequency of Web Use}

The students reported their Web use frequencies as the following: never $(n=4,0.6 \%)$; between 1 and 5 hours a month $(n=86,11.9 \%)$; between 1 and 5 hours a week ( $n=291,40.3 \%)$; and everyday $(n=341,47.2 \%)$. The never users were excluded from the analysis in this section since their numbers were insufficient. Also, crosstab results indicated that significantly more PC owner students use the Web everyday $(n=279,63 \%)$ in comparison to the non-PC-owners $(n=62$, $22.5 \%)\left(\chi^{2}=128.40, \mathrm{df}=2, \mathrm{p}=.000\right)$. These findings reflect that the PC-owner students use the Web more frequently than the non-PC-owners.

As displayed in Table 9, the one-way ANOVA results on differences based on the Web use frequencies indicated that there were significant differences in the mean scores of the students on all subscales: usefulness $(\mathrm{F}=12.561, \mathrm{df}=2 / 715, \mathrm{p}=.000)$; Web-based learning $(\mathrm{F}=5.579, \mathrm{df}=$ $2 / 715, \mathrm{p}=.004)$; self-efficacy $(\mathrm{F}=64.898, \mathrm{df}=2 / 715, \mathrm{p}=.000)$; and affective $(\mathrm{F}=34.972, \mathrm{df}=$ $2 / 715, \mathrm{p}=.000$ ). Specifically, the post hoc tests showed that everyday users had significantly higher mean scores on the usefulness, Web-based learning, self-efficacy, and affective subscales than the Web users with lower frequency (i.e., $1-5$ hours in a week, $1-5$ hours in a month). Moreover, the students who use the Web between one and five hours a week had significantly higher attitude mean scores on the usefulness, self-efficacy, and affective subscales than those students who use the Web between one and five hours in a month.

Table 9

Differences in Perceptions toward the Web Based on Web-Usage Frequency 


\begin{tabular}{|c|c|c|c|c|c|c|c|c|}
\hline \multirow[b]{2}{*}{ Web-usage frequency } & \multirow[b]{2}{*}{$\mathrm{N}$} & Usefulness & \multicolumn{2}{|c|}{$\begin{array}{l}\text { Web-based } \\
\text { learning }\end{array}$} & \multicolumn{2}{|c|}{ Self-efficacy } & \multicolumn{2}{|c|}{ Affective } \\
\hline & & $\bar{X} \quad(\mathrm{sd})$ & $\bar{X}$ & $\mathrm{sd}$ & $\bar{X}$ & sd & $\bar{X}$ & sd \\
\hline (1) $1-5$ hours in a month & 86 & $31.74(5.65)$ & 18.25 & 4.46 & 12.26 & 3.86 & 13.30 & 2.90 \\
\hline (2) $1-5$ hours in a week & 291 & $33.19(5.80)$ & 19.27 & 4.24 & 13.88 & 3.42 & 14.72 & 3.13 \\
\hline (3) Everyday & 341 & $34.70(5.07)$ & 19.92 & 4.36 & 16.12 & 2.97 & 16.07 & 2.93 \\
\hline F (ANOVA) & & $\begin{array}{l}12.561 \\
(\mathrm{P}=.000)^{*}\end{array}$ & $\begin{array}{l}5.579 \\
(\mathrm{P}=.00\end{array}$ & & $\begin{array}{l}64.898 \\
(\mathrm{P}=.00\end{array}$ & & $\begin{array}{l}34.972 \\
(\mathrm{P}=.00\end{array}$ & \\
\hline Tukey HSD & & $\begin{array}{l}(3)>(1)^{*} \\
(3)>(2)^{*}\end{array}$ & $(3)>(1$ & & $(3)>(2$ & $(1)^{*}$ & $(3)>(2$ & $(1)^{*}$ \\
\hline
\end{tabular}

$* \mathrm{P}<0.05$

\section{Main and Interaction Effects of Socio-Economic Background, Gender, and PC Ownership on Web Attitude}

The descriptive results in Table 10 showed that PC-owner students $(N=445)$ had notably higher mean scores on most subscales than the non-PC-owner students $(N=277)$ within the same monthly income groups except for in the $1501-2250$ NTL and $2251-3000$ NTL income groups on the Web-based learning subscale. The two-way ANOVA results in Table 11 showed that PC ownership (PCO) had significant main effects on the Web attitudes of the students on the usefulness, self-efficacy, and affective subscales. However, the monthly family income (MFI) did not have any notable main effect on the attitudes of students on any of the subscales.

Table 10

Descriptive Statistics for the Attitudes on the Subscales depending on Monthly Family Income and PC Ownership

\begin{tabular}{llllll}
\hline & & & Web-based & Self- \\
Monthly family & PC ownership & Usefulness & learning \\
income & efficacy & Affective \\
\hline$<750$ NTL & Yes $42(36,2 \%)$ & 35.33 & 20.04 & $\bar{X}$ & $\bar{X}$ \\
& No $74(63,8 \%)$ & 32.89 & 18.78 & 12.79 & 16.61 \\
& Total 116 & 33.77 & 19.24 & 13.81 & 14.87 \\
\hline $750-1500$ NTL & Yes $196(55,5 \%)$ & 33.79 & 19.59 & 15.28 & 15.35 \\
& No $157(44,5 \%)$ & 33.00 & 19.08 & 13.74 & 14.91 \\
& Total 353 & 33.44 & 19.36 & 14.60 & 15.15 \\
\hline $1501-2250$ NTL & Yes 132 (79,5\%) & 34.16 & 19.59 & 15.63 & 15.56 \\
& No 34 (20,5\%) & 31.58 & 20.00 & 13.02 & 14.38
\end{tabular}




\begin{tabular}{llllll} 
& Total 166 & 33.63 & 19.67 & 15.10 & 15.32 \\
\hline 2251-3000 NTL & Yes 52 (88,1\%) & 35.51 & 19.51 & 15.88 & 15.48 \\
& No 7 (11,9\%) & 33.14 & 19.57 & 15.42 & 14.42 \\
& Total 59 & 35.23 & 19.52 & 15.83 & 15.35 \\
\hline$>3000$ NTL & Yes 23 (82,1\%) & 36.08 & 20.26 & 16.60 & 16.30 \\
& No 5 (17,9\%) & 27.80 & 17.60 & 10.60 & 11.60 \\
& Total 28 & 34.60 & 19.78 & 15.53 & 15.46 \\
\hline
\end{tabular}

As indicated in Table 10, numbers and percentages (\%) of the PC-owner students increase notably as their socio-economical levels in terms of monthly family income increase. According to these findings, the students with higher socio-economical levels (e.g., 2251 - 3000 NTL) are more likely to own a PC than the students with lower socio-economical levels (e.g., < 750 NTL).

Table 11

The Two-Way ANOVA Results on the Web Attitude depending on Monthly Family Income and PC Ownership

\begin{tabular}{|c|c|c|c|c|c|c|c|c|c|c|c|c|c|}
\hline \multicolumn{5}{|c|}{ Usefulness } & \multicolumn{3}{|c|}{ Web-based learning } & \multicolumn{3}{|c|}{ Self-efficacy } & \multicolumn{3}{|c|}{ Affective } \\
\hline Source & df & $\begin{array}{l}\text { Mean } \\
\text { Square }\end{array}$ & $\mathrm{F}$ & $\mathrm{P}$ & $\begin{array}{l}\text { Mean } \\
\text { Square }\end{array}$ & $\mathrm{F}$ & $\mathrm{P}$ & $\begin{array}{l}\text { Mean } \\
\text { Square }\end{array}$ & $\mathrm{F}$ & $\mathrm{P}$ & $\begin{array}{l}\text { Mean } \\
\text { Square }\end{array}$ & $\mathrm{F}$ & $\mathrm{P}$ \\
\hline MFI & 4 & 34.91 & 1.17 & .319 & 5.431 & 2.83 & .889 & 14.388 & 1.23 & .293 & 6.60 & .682 & .605 \\
\hline $\mathrm{PCO}$ & 1 & 551.91 & 18.62 & $.000 *$ & 32.199 & 1.67 & .196 & 365.99 & 31.51 & $.000^{*}$ & 208.61 & 21.51 & $.000^{*}$ \\
\hline $\begin{array}{l}\text { MFI x } \\
\text { PCO }\end{array}$ & 4 & 72.38 & 2.44 & $.045^{*}$ & 14.75 & .769 & .546 & 31.49 & 2.71 & $.029 *$ & 40.86 & 4.21 & $.002 *$ \\
\hline
\end{tabular}

As indicated in Table 11, monthly family income and PC ownership had significant interaction effects on the Web attitudes of the students on the usefulness, self-efficacy, and affective subscales. The findings revealed that the effects of the students' monthly family incomes on the attitudes on the usefulness, self-efficacy, and affective subscales differ significantly depending on their PC ownership.

In addition, the descriptive statistics indicated that the PC-ownership rate among the male students $(63.7 \%, n=211$ out of 331$)$ is higher than that among the female students $(59.8 \%, n=$ 234 out of 391). According to these results, the male students are more likely to own a PC than the female students although the difference in the rates (3.9\%) is not very large.

Moreover, the two-way ANOVA results in Table 12 indicated that PC ownership had significant main effects on the Web attitudes of the students on the usefulness, self-efficacy, and affective subscales. Additionally, the results indicated that gender had a significant main effect on the 
attitudes of the students on the self-efficacy subscale; males had a notably higher mean $(\bar{X}=$ 15.25) than that of females ( $\bar{X}=14.27)$.

Furthermore, the interaction effect between gender and PC ownership was significant on the attitudes of the students only on the affective subscale on which PC-owner males $(\bar{X}=15.76)$ and females $(\bar{X}=15.44)$ had notably higher means than those of non-PC-owner males $(\bar{X}=14.00)$ and females $(\bar{X}=14.87)$.

Table 12

The Two-Way ANOVA Results on the Web Attitude Depending on Gender and PC Ownership

\begin{tabular}{|c|c|c|c|c|c|c|c|c|c|c|c|c|c|}
\hline \multicolumn{5}{|c|}{ Usefulness } & \multicolumn{3}{|c|}{ Web-based learning } & \multicolumn{3}{|c|}{ Self-efficacy } & \multicolumn{3}{|c|}{ Affective } \\
\hline Source & $\mathrm{df}$ & $\begin{array}{l}\text { Mean } \\
\text { Square }\end{array}$ & $\mathrm{F}$ & $\mathrm{P}$ & $\begin{array}{l}\text { Mean } \\
\text { Square }\end{array}$ & $\mathrm{F}$ & $\mathrm{P}$ & $\begin{array}{l}\text { Mean } \\
\text { Square }\end{array}$ & $\mathrm{F}$ & $\mathrm{P}$ & $\begin{array}{l}\text { Mean } \\
\text { Square }\end{array}$ & $\mathrm{F}$ & $\mathrm{P}$ \\
\hline Gender & 1 & 29.62 & .991 & .320 & .279 & .015 & .904 & 112.48 & 9.76 & $.002 *$ & 13.22 & 1.35 & .245 \\
\hline $\mathrm{PCO}$ & 1 & 458.30 & 15.32 & $.000 *$ & 55.74 & 2.917 & .088 & 789.13 & 68.47 & $.000 *$ & 230.39 & 23.61 & $.000 *$ \\
\hline Gender & & & & & & & & & & & & & \\
\hline $\begin{array}{l}\mathrm{x} \\
\mathrm{PC}-\mathrm{O}\end{array}$ & 1 & 13.38 & .448 & .504 & 2.54 & .133 & .715 & 16.59 & 1.44 & .231 & 60.52 & 6.20 & $.013 *$ \\
\hline
\end{tabular}

\section{Discussion}

The findings of the study regarding the Web use pattern of Turkish undergraduate students indicated that research $(86.3 \%, n=623)$ was the highest activity, followed by e-mail $(76.3 \%, n=$ $551)$, while shopping $(18.3 \%, n=132)$ was the lowest activity, which is similar to the findings of prior studies conducted in Malaysia (Sam et al., 2005; Luan, et al., 2005).

In regard to the gender issue, the findings of this study revealed that significantly more Turkish male students have used the Web for shopping, software downloading, news reading, participation in discussion groups and forums, and entertainment activities in comparison to the female students. However, significantly more Turkish female students have used the Web for research purposes as compared to the male students. These findings suggest that there are notable variations in the Internet activities between males and females although the gender differences in some Internet activities (i.e., e-mail, chat, education) are negligible, which is similar to the findings of Durndell and Haag (2002). Also, the Turkish male students reflected significantly higher attitudes on the self-efficacy subscale than the females, although no significant gender differences were found on the usefulness, Web-based learning, and affective subscales. The finding of this study about the gender difference on the self-efficacy subscale supports prior 
studies (Torkzadeh \& Koufteros, 1994; Durndell, \& Haag, 2002), which revealed that males tend to report greater computer self-efficacy.

Moreover, the findings of the study indicated that the students from lower socio-economic backgrounds in terms of monthly family incomes reflected significantly lower attitudes on the self-efficacy subscale. Furthermore, notably fewer students in the lower monthly family income group (i.e., <750 NTL) have used the Web for shopping, software downloading, e-mail, and entertainment activities as compared to the numbers of the students in the higher monthly family income groups, similar to the findings of a prior study in India (Haseloff, 2005).

Furthermore, the results of the present study revealed that the students who have used the Web for the nine common Web activities indicated significantly more positive attitudes toward the Web on most subscales. Moreover, the students with higher Web experience in terms of frequency of Web use had higher attitudes on all subscales. Also, the findings indicated that the PC-owner students, who are more likely to use the Internet more frequently (i.e., everyday), had significantly higher attitudes on the usefulness, self-efficacy, and affective subscales than the non-PC-owners. These findings suggest that increased Web experience is closely associated with more positive attitudes toward the Web, similar to the findings of prior studies (e.g., Liaw, 2002b; Durndell \& Haag, 2002; Luan et al., 2005; Anderson \& Reed, 1998).

Furthermore, the two-way ANOVA results indicated that PC-ownership had significant main effects on the Web attitudes of the students on the usefulness, self-efficacy, and affective subscales. Moreover, monthly family income and PC-ownership had significant interaction effects on the Web attitudes of students on the usefulness, self-efficacy, and affective subscales. The interaction effect between gender and PC-ownership was significant on the attitudes of the students only on the affective subscale on which PC-owner males and females had notably higher mean scores than those of non-PC-owner males and females. The findings revealed that the effects of the students' monthly family incomes on the attitudes on the usefulness, self-efficacy and affective subscales, and the effect of gender on the affective subscale vary depending on the students' PC-ownership. According to these findings, it can be stated that Turkish students' attitudes or perceptions toward the Web as a learning tool are mostly related to their computer and Web experience rather than gender and socio-economic background. The findings of this study regarding the effect of Web or computer experience on the Web attitudes of the students support the findings of prior studies (Hong et al, 2003; Luan et al., 2005), which indicate that computer and Internet experience promotes positive attitudes or perceptions toward the Web as a learning tool.

\section{Conclusion}

The main purpose of the study was to investigate Turkish undergraduate students' perceptions of the Web as a learning tool and to analyze whether their perceptions differ based on gender, socioeconomic background, and computer (e.g., PC ownership) and Web experience (e.g., Web use frequency). The findings of the study and prior studies in other societies (e.g., Hong et al, 2003; 
Luan et al., 2005; Liaw, 2002b) suggest that the students' perceptions or attitudes toward the Web as a learning tool are highly related to their computer and Web experience. The students with more computer and Web experience are more likely to have more positive perceptions or attitudes toward the Web as a learning tool. As a result, although differences based on gender and socioeconomic backgrounds were found on the self-efficacy subscale, the findings of this study suggest that perceptions of students toward the Web as a learning tool are mostly associated with their computer and Web experience. 


\section{References}

Akpınar, Y. \& Bayramoğlu, Y. (2008). Promoting teachers' positive attitude towards Web use: A study in Web site development. The Turkish Online Journal of Educational Technology, 7(3). http://www.tojet.net/articles/735.htm

Anderson, D. K., \& Reed, W. M. (1998). The effects of Internet instruction, prior computer experience, and learning style on teachers' Internet attitudes and knowledge. Journal of Educational Computing Research, 19(3), 227-246.

Brinkerhoff, J. \& Koroghlanian, C. M. (2005). Student computer skills and attitudes toward Internet-delivered instruction. Journal of Educational Computing Research, 32(1), 27-56.

Bozionelos, N. (2004). Socio-economic background and computer use: The role of computer anxiety and computer experience in their relationship. International Journal of HumanComputer Studies, 61(5), 725-746.

Business Monitor International (2008). The Turkey Information Technology Report 2008. http://www.businessmonitor.com/it/turkey.html

Carswell, L., Thomas, P., Petre, M., Price, B., Richards, M. (2000). Distance education via the Internet: The student experience. British Journal of Educational Technology, 31(1), 2947.

Durndell, A. \& Haag, Z. (2002). Computer self efficacy, computer anxiety, attitudes toward the Internet and reported experience with the Internet, by gender, in an East European sample. Computers in Human Behavior, 18, 521-535.

Hong, K.-S., Ridzuan, A. A., \& Kuek, M.-K. (2003). Students' attitudes toward the use of the Internet for learning: A study at a university in Malaysia. Educational Technology \& Society, 6(2), 45-49.

Haseloff, A. M. (2005). Cybercafes and their potential as community development tools in India. The Journal of Community Informatics, 1(3), 53-65. http://www.ci-journal.net/index.php/ciej/article/view/226/182

Keller, C. \& Cernerud, L. (2002). Students' perceptions of e-learning in university education. Journal of Educational Media, 27(1), 55 - 67.

Liaw, S. S. (2002a). Understanding user perceptions of World-wide web environments. Journal of Computer Assisted Learning, 18(2), 137-148. 
Liaw, S. S. (2002b). An Internet survey for perceptions of computers and the World Wide Web: Relationship, prediction, and difference. Computers in Human Behavior, 18(1), 17-35.

Luan, W. S., Fung, N. S., Nawawi, M., \& Hong, T. S. (2005). Experienced and inexperienced Internet users among pre-service teachers: Their use and attitudes toward the Internet. Educational Technology \& Society, 8(1), 90-103.

Microsoft Encarta Online Encyclopedia (2007). World Wide Web. http://encarta.msn.com/encyclopedia_761579872/World_Wide_Web.html

Sam, H. K., Othman, A. E. A., \& Nordin, Z. S. (2005). Computer self-efficacy, computer anxiety, and attitudes toward the Internet: A study among undergraduates in Unimas. Educational Technology \& Society, 8(4), 205-219.

Schumacher, P. \& Morahan-Martin, J. (2001). Gender, Internet and computer attitudes and experiences. Computers in Human Behavior, 17, 95-110.

Usun, S. (2003). Educational uses of Internet in the world and Turkey: A comparative review.

Turkish Online Journal of Distance Education-TOJDE, 4(3).

http://tojde.anadolu.edu.tr/tojde11/index.htm

Tekinarslan, E. (2008). Attitudes of Turkish distance learners toward Internet-based learning: an investigation depending on demographical characteristics. Turkish Online Journal of Distance Education-TOJDE, 9(1). http://tojde.anadolu.edu.tr/tojde29/pdf/article_4.pdf

Thompson, B. \& Daniel, L.G. (1996). Factor analytic evidence for the construct validity of scores: A historical overview and some guidelines. Educational and Psychological Measurement, 56(2), 197-208.

Torkzadeh, G. \& Koufteros, X. (1994). Factoral validity of a computer self efficacy scale and the impact of computer training. Educational and Psychological Measurement, 54(3), 813921.

Yang, B. \& Lester, D. (2003). Liaw's measures of attitudes toward computers and the Internet: a supportive comment. Computers in Human Behavior, 19(5) 649-651.

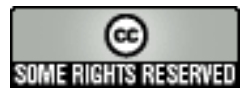

